Article

\title{
The Politics of Syrian Refugees in Turkey: A Question of Inclusion and Exclusion through Citizenship
}

\author{
Sebnem Koser Akcapar ${ }^{1, *}$ and Dogus Simsek ${ }^{2}$ \\ ${ }^{1}$ Department of Sociology, Koç University, 34450 Istanbul, Turkey; E-Mail: sakcapar@ku.edu.tr \\ ${ }^{2}$ College of Social Sciences and Humanities, Koç University, 34450 Istanbul, Turkey; E-Mail: dsimsek@ku.edu.tr \\ * Corresponding author
}

Submitted: 22 December 2017 | Accepted: 12 March 2018 | Published: 29 March 2018

\begin{abstract}
Turkey began to receive refugees from Syria in 2011 and has since become the country hosting the highest number of refugees, with more than 3.5 million Syrians and half a million people of other nationalities, mainly from Afghanistan, Iraq and Iran. An important turning point regarding the legal status of Syrian refugees has come with recent amendments to the Turkish citizenship law. Based on ongoing academic debates on integration and citizenship, this article will explore these two concepts in the case of Syrian refugees in Turkey. We will argue that the shift in the Turkish citizenship law is a direct outcome of recent migration flows. We further argue that the citizenship option is used both as a reward for skilled migrants with economic and cultural capital and as a tool to integrate the rest of the Syrians. It also reflects other social, political and demographic concerns of the Turkish government. Using our recent ethnographic study with Syrians and local populations in two main refugee hosting cities in Turkey, Istanbul and Gaziantep, we will locate the successes and weaknesses of this strategy by exemplifying the views of Syrian refugees on gaining Turkish citizenship and the reactions of Turkish nationals.
\end{abstract}

\section{Keywords}

citizenship; exclusion; inclusion; integration; refugees; Syrians; Turkey

\section{Issue}

This article is part of the issue "The Transformative Forces of Migration: Refugees and the Re-Configuration of Migration Societies", edited by Ulrike Hamann and Gökçe Yurdakul (Humboldt University of Berlin, Germany).

(C) 2018 by the authors; licensee Cogitatio (Lisbon, Portugal). This article is licensed under a Creative Commons Attribution 4.0 International License (CC BY).

\section{Introduction}

In 2011, Turkey started to receive refugees from Syria fleeing the eruption of violence. Since then, the civil war has escalated in Syria, and Turkey has become the country hosting the highest number of refugees in the world. According to the Directorate General of Migration Management of Turkey (DGMM), the number of Syrian refugees under temporary protection settled in Turkey stands at more than 3.5 million as of February $2018 .{ }^{1}$ Obviously, there are political, economic, de- mographic and socio-cultural implications of this mass movement for the wider society and for the refugees themselves. Yet, two important factors are usually overlooked in these flows and missing in mere statistics available on Syrian refugees. The first one is about the diversity of the Syrian population in Turkey, since they come from different socio-economic, ethnic and religious backgrounds. The second point has to do with their legal status. Turkey adopted a new Law on Foreigners and International Protection (LFIP) in 2013 (Law No. 6458) and additional legislation in 2014 that

\footnotetext{
${ }^{1}$ Excluding the number of unregistered and those living with residence permits, the number of Syrian refugees under temporary protection in Turkey reached 3,531,416 as of February 2018. The majority of Syrians live in urban centers and only $8 \%$ live in camps. See recent statistics on the demographics of Syrians under temporary protection in cities and camps at DGMM (2018).
} 
changed their legal status from temporary guests to those under temporary protection. ${ }^{2}$

Although many Syrians enjoy certain rights under the temporary protection regime, they are still not considered to be "refugees" due to Turkey's retention of the geographical limitation clause in the 1951 Geneva Convention on Refugees. ${ }^{3}$ There are also thousands of Syrians with residence permits without temporary protection status and an unknown number of Syrian irregular migrants. ${ }^{4}$ Their "liminal" situation and temporary status not only automatically limit their opportunities, like permanent settlement in Turkey, but also hinder the political will to put proper integration regimes in place at the national level even after seven years.

An important turning point regarding the legal status of Syrian refugees was the amendment to the citizenship law and the surrounding heated debates on the naturalization of Syrians. As mentioned earlier, Turkey has already provided "temporary protection" to Syrian refugees, which somewhat eased their access to certain rights, including access to public healthcare, education of children, and participation in labor markets via the new law on work permits. The idea of granting Turkish citizenship to Syrians who have found refuge in Turkey was first voiced in 2016 by President Erdoğan in Kilis, a city near the border with Syria with pre-existing close kin ties between Syrians and Turkish nationals (Milliyet, 2016). Kilis is an interesting case study to consider, as the number of Syrian refugees has gradually exceeded the number of local inhabitants and the city has de facto become a buffer zone between Syria and Turkey. Such public announcements triggered a debate partly due to the lack of legal status of Syrians as "refugees" or as "permanent residents/denizens" in the first place and partly because they fueled nationalist fears that the temporariness of Syrians' stay would be replaced with permanence (Koser Akcapar, 2018). In order to mitigate the political backlash and public outrage, government officials clarified that granting citizenship to Syrians would require they meet exceptional criteria based on high skill and higher education levels of applicants. ${ }^{5}$

Considering the intricate relationship between integration and citizenship in the case of refugees, this article specifically explores the changing concept of citizenship in Turkey over the years, but especially after the arrival of Syrian refugees, and evaluates the conditions and rationale for extending Turkish citizenship to Syrians. In exploring the linkage between integration and citizenship in the case of Syrian refugees in Turkey, this article exam- ines the following questions: Why has the Turkish government changed its long-standing citizenship model based on jus sanguinis (descent or blood principle)? What factors play crucial roles in the changing nature of citizenship in the Turkish case? What does gaining Turkish citizenship mean for Syrian refugees? How is gaining Turkish citizenship interlinked with the integration of Syrian refugees? We argue that the main reasons for this shift in citizenship policy are a direct outcome of mass migration, particularly Syrian refugee flows. Although Turkish citizenship law seems to have become more inclusive through the amendment, we also argue that the law remains selective, targeting Syrians with cultural and economic capital as well as mostly those coming from a Sunni background. Based on the interrelated citizenship and integration concepts in migration literature and the changing Turkish citizenship regime, we begin the article by setting out a theoretical framework before outlining the research methods implemented for this study. Using interview data, we then examine the life experiences of Syrian refugees in two main cities, Istanbul and Gaziantep, and their views on gaining citizenship in Turkey. As this protracted and mostly urban refugee problem has also generated problems and tensions with the local populations, we will also discuss public reactions towards Syrians' citizenship acquisition. The final section evaluates the government policies and concludes with recommendations.

\section{Theoretical Framework: Integration and Path to Citizenship of Refugee Populations}

The terms "citizenship" and "integration" have been used to refer to different stages of immigrants' settlement in the academic literature. Citizenship expresses different things to many people (Joppke, 2007, p. 37) and its meaning varies among nation-states, migrants and refugees. While for some scholars, citizenship represents the capstone of integration processes (Ager \& Strang, 2008), for others it is an important means to secure full inclusion in the receiving society (Massey \& Bartley, 2005). In general, it is defined as:

A formal legal status that links individuals to a state or another established polity (such as the European Union or a federal province), a bundle of legal rights and duties associated with the status, including civil liberties, rights to democratic representation, and social rights to education, health care, and

\footnotetext{
${ }^{2}$ On 22 October 2014, the Council of Ministers of the Republic of Turkey issued a regulation on temporary protection. The law lists six types of residence permits: short-term, long-term, family, student, humanitarian, and victims of trafficking. The LFIP also regulates their access to health, education, social assistance and the labor market. The law was further amended in 2016.

${ }^{3}$ Turkey is a signatory of the Geneva Convention on Refugees, but it is one of the few countries retaining the geographical limitation clause lifted in 1967 , which is tied to the long-stalled full membership negotiations between Turkey and the EU and the prevalent fear that Turkey will be given the duty of safeguarding the external borders of the EU with no or little prospects for international burden-sharing. Although people coming from outside Europe cannot be given refugee status in Turkey because of political concerns, we have used the term refugee throughout the article.

${ }^{4}$ The DGMM reports that there are 65,000 Syrians staying in Turkey with residence permits. Although the number of unregistered Syrians in Turkey is unknown, the number of Syrians voluntarily leaving Turkey for Syria via the border gates suggests high numbers (interview with UNHCR official in Gaziantep, Karkamış border gate).

5 See Sözcü daily dated 6 July 2017: http://www.sozcu.com.tr/2017/gundem/yildirimdan-suriyeliler-mesaji-1921618/
} 
protection from poverty risks, a set of responsibilities, virtues, and practices that support democratic self-government and a collective identity that can be shared across distinctions of class, race, gender, religion, ethnic origin, or way of life. (Bauböck, 2008, p. 3)

It basically refers to who is included or excluded in any given society in terms of civil, political or economic rights (Hammar, 1990).

In this day and age, different practices of citizenship highlight the changing nature of citizenship globally. According to Gardner's "new citizenship model," the concept of citizenship has been divorced from that of nationality (quoted in Kibreab, 2003, pp. 44-45). Similarly, Kymlicka (2003, p. 195) notes that while the idea of "national citizenship" is becoming obsolete, there is a new understanding of citizenship that demands rights in return for responsibilities. The traditional understanding of citizenship, which refers to a unitary status highlighting a strong sense of belonging to a single nation-state, is changing due to the emergence of a global economy, the use of new information technologies, free movement of capital and goods, the development of supra-national institutions, universal norms of governance including human rights and democracy, and cross-cultural awareness as byproducts of the process of globalization (Castles \& Davidson, 2000). This is especially evident with the increase in cross-border political, economic, social and cultural relationships of individuals. Reforms of citizenship law, paving the way for a dual citizenship option, address the issues exacerbated by globalization and increasing transnationalism and are currently linked with the challenges facing the nation-state model at the end of twentieth century (Castles \& Davidson, 2000). Soysal calls this understanding of citizenship "post-national citizenship" and argues that "the state is no longer an autonomous and independent organization closed over a nationally defined population" (1994, pp. 163-164). Instead, what we have is a system of constitutionally interconnected states with a multiplicity of memberships. Soysal's model of "post-national citizenship" is based on universal human rights, which highlights the fact that access to rights is no longer limited by a unitary state-bound citizenship status but instead locates citizenship and its practices in transnational understandings that span the borders of nation-states.

"Transnational citizenship" has been popularized in the literature to describe a concept of citizenship that highlights the cross-border activities of individuals. It can be summarized as "a triangular relationship between individuals and two or more independent states in which these individuals are simultaneously assigned membership status and membership-based rights or obligations" (Bauböck, 2007, p. 2395). This conceptualization highlights that changes in rights to dual citizenship and institutional transformations of membership and legal rights have occurred due to migration, globalization, mobility and diversity. Taking the case of Turkish immi- grants living in Germany, Kaya's (2012) research illustrates that German-Turks construct transnational spaces where they meet their political, economic, social and cultural needs and perform citizenship practices that cross the borders of sending and receiving countries. These new conceptualizations of citizenship, including "postnational citizenship," "dual citizenship" and "transnational citizenship," express the changing nature of belonging and role of nation-states in the practices of citizenship. As the number of international migrants increases, the number of dual citizens and the countries allowing dual citizenship also increases.

It is important to note that the meaning of citizenship differs among various types of migrants. For refugees, for instance, acquiring citizenship is more about human security, gaining a higher status in the receiving society and having access to more rights. As pointed out by Kibreab, "non-nationals, particularly refugees, are denied many of the rights enjoyed by nationals and are consequently considered as 'other,' removed from the political, social, economic and cultural life of host societies" (2003, p. 47). Therefore, citizenship for refugees is associated with safety and securing a better future (Stewart \& Mulvey, 2014, p. 1033).

In traditional immigration and refugee-hosting countries, citizenship access among refugees has long been discussed in relation to their allegiance or as a facilitating factor in integration processes. Similar to citizenship, the concept of integration is also a controversial topic since "there is no single generally accepted definition, theory or model of immigrant and refugee integration" (Castles, Korac, Vasta, \& Vertovec, 2002, p. 112). At a minimum, the concept of integration embodies certain rights and adjustments of refugees (Strang \& Ager, 2010). Similarly, gaining citizenship can be regarded as a fundamental part of refugee integration, as it represents one of the key structural factors of refugee integration, i.e., access to rights. Therefore, the path to citizenship for refugees is considered one of the main stepping stones towards integration (Ager \& Strang, 2004, 2008). Ager and Strang (2008) proposed a comprehensive approach to integration by focusing on access to health services, labor markets and education as well as the willingness of migrants and refugees to be part of the receiving society. The final stage of integration process is the acquisition of citizenship, usually seen as a "reward" from a nationstate to integrated refugees. However, the relationship between refugee integration and citizenship is complex and remains contested (Koska, 2015; Smyth, Stewart, \& Da Lomba, 2010; Stewart \& Mulvey, 2014).

Citizenship and integration are indeed interrelated concepts and their intricate relationship is not only influenced by government policies, but also has an impact on many political, economic and socio-cultural aspects of a society. What is usually missing in these debates are the refugees' decisions in response to a given citizenship opportunity. In analyzing the role of citizenship in the integration processes of refugees, two dimensions of the con- 
cept of citizenship should be taken into account. The first highlights the legal status that regulates one's membership in a state and the rights associated with this membership that are determined by governmental authority. The other is related to the sense of identity and belonging that members of a particular polity associate with the new citizenship status (Koska, 2015). It is important to recognize that refugees are not passive objects of such legal structures, but rather active agents who make choices between available legal structures (Turton, 2003, quoted in Koska, 2015). For refugees, gaining citizenship mostly means regaining freedom and mobility, having the ability to use the rights that come with this legal status, and gaining access to power structures by ensuring their inclusion in a host society in which they feel safe and secure (cf. Bloch, 2000; Morrell, 2009; Nunn, McMichael, Gifford, \& Correa-Velez, 2016; Vertovec, 2006). As argued by Kibreab (2003), access to citizenship status revolves around refugees' decision whether to stay in the receiving country or not. Whether citizenship is understood as the final stage of integration processes or forms the basis of integration by nation-states, for refugees, it simply refers to safety, stability and acceptance by the members of receiving society.

For Syrians, the acquisition of Turkish citizenship would provide a way to reach a safe legal status and stability, as they are under "temporary" protection and are not even legally accepted as refugees. They are usually facing "liminality" 6 along with a myriad of problems such as racism, discrimination, economic and social problems. Consequently, the acquisition of Turkish citizenship is important for many Syrians, not only to reach safety and attain "ontological security" (Giddens, 1991), but also to have access to more legal employment opportunities and be accepted by the wider society, thereby making it possible to abandon their "liminal" state. In our study, we realized that Syrian refugees also frequently opt for dual citizenship or transnational citizenship, mainly to gain rights and retain privileges in both contexts. The next section will summarize the recent changes in the Turkish citizenship regime and government policies. It also underlines the main reasons why citizenship is used as a reward for skilled and educated individuals, but also serves as an essential tool towards integration, especially in the case of Syrians.

\section{The Changing Turkish Citizenship Regime}

Apart from refugees' attitudes towards citizenship, increasing migration flows and life in heterogeneous societies have transformed nation-states and forced them to replace earlier fixed concepts of citizenship with more flexible re-definitions. Turkey is no exception. Recently, Turkish authorities have duly accepted that Turkey has become a destination country for migrants. With the large number of refugees and migrants in its territory, this has become even more evident after the arrival of Syrians. In fact, Turkey started to make changes and reforms in migration policies not only to address pressing issues resulting from the large number of flows over the course of the past seven years, but also for the sake of the EU Accession Process since the early 2000s. Other than laws specifically addressing asylum issues (i.e., the LFIP adopted in 2013 (Law No. 6458) and the Regulation on Temporary Protection adopted in 2014), two laws are directly linked with migration flows. The first one is the law on work permits for foreigners (No. 4817), which was put into effect in 2003. The law mainly addresses the growing number of irregular and circular economic migrants working in the informal sector who were attracted by Turkey's favorable economic position within the region. Wage differentials compared to their countries of origin is another factor in attracting labor migrants from diverse locations, including Central Asia, Eastern Europe, Africa and South Asia. Obviously, not only labor migrants but also asylum seekers need to work to make ends meet. Legal changes continued with the enactment of the International Labor Force (Law No. 6735), which became the primary legislation for foreign labor and replaced the abrogated Law No. 4817 as of 13 August 2016. The purpose of the Law was to determine and monitor a policy regarding the international labor force and to extend work permits according to certain criteria. The current legal framework includes both employer-led and points-based approaches, with an emphasis on selective labor migration. The introduction of the Turquoise Card is an indication of this emphasis; it enables access to permanent work permits for those considered of strategic importance, determined mainly by a high educational level, professional experience, and investments in Turkey. It also extends residence permits for the spouse and children of holders of Turquoise Cards. Because of this law, the LFIP was amended on 29 October 2016 as well, with regard to residence and work permits given to foreign students. ${ }^{7}$

The second significant recent legal change is to the Turkish Citizenship Law. Turkish citizenship practice was primarily based on the jus sanguinis principle, as determined under the Citizenship Law dated 1928 (No. 1312), Law on Settlement (dated 1934, No. 2510), and Citizenship Law dated 1964 (No. 403). Under this principle, descent (Turkish ethnicity) and heritage (Sunni Muslims) play an important role in Turkish citizenship (Kirişçi, 2000). In an effort to address increasing trends in irregular migration, trafficking and fake intermarriages, Turkey revised its citizenship laws in 2003 by creating a naturalization option for foreign nationals who meet certain criteria. According to the Citizenship Law (No. 5901), marrying a Turkish citizen made it possible for both men and

\footnotetext{
${ }^{6}$ Liminality is a term coined by Van Gennep (1908) in analyzing rites of passage and was later elaborated on by Turner (1974). The liminal state of Syrian refugees refers to the phase between separation (leaving Syria behind) and reincorporation (resettlement in a third country and/or acceptance in Turkey). Their liminality also results from the temporary status given to Syrians in Turkey and it leaves them with a feeling of being neither here nor there.

${ }^{7}$ For amendments to the LFIP see DGMM (2016).
} 
women to acquire citizenship after three years of marriage. In 2009, further changes were adopted, such as providing protection for stateless children if they are unable to acquire their parents' citizenship (No. 5901, Article 11: 1), ${ }^{8}$ citizenship under exceptional circumstances (Article 14: b), naturalization for adults if stateless and/or after five years of uninterrupted residence in Turkey and/or in possession of immoveable property in Turkey, making investments in Turkey and transferring their work place to Turkey (Article 15 (a)(b)(c) respectively), pending approval from the Council of Ministers (Article 21). ${ }^{9}$ These series of amendments de facto changed the citizenship concept from one solely based on Turkish descent, thus bringing Turkey more in line with immigration countries of the world. Whilst opening pathways to regular migration, the Turkish citizenship law specifically denies citizenship to refugees and asylum seekers as well as those staying in Turkey illegally. Refugees in Turkey are generally seen as temporary guests who should return to their countries of origin whenever the reasons for displacement cease to exist.

More recently, on December 12, 2016, another amendment to the Turkish citizenship law was introduced and accepted by the Council of Ministers and signed by the President (Decision number: 2016/9601). First of all, exceptional citizenship criteria were described in detail under Article 12 (paragraph 1b). These are: 1) making a capital investment of at least two million USD in Turkey; 2) purchasing immovable property worth at least one million USD; 3 ) securing employment for at least 100 workers; 4) having at least three million USD or equivalent deposits in Turkish banks, provided there are no withdrawals for at least three years; and 5) keeping government bonds and bills equaling at least three million USD for three years. Other than the investment and capital criteria, exceptional citizenship acquisition will be made available to those who stay in the country legally and have already contributed and/or have the potential to contribute to the Turkish society in the fields of science, economy, social life, sports, culture and arts. In line with the changes, it seems apparent that Turkey wants to attract more migrants with money and financial capacity by offering them the chance to be naturalized.

According to a new report on Syrian refugees in Turkey, published by the Turkish Parliament's Refugee Rights Sub-commission, more than 30,000 Syrian nationals had been granted citizenship in Turkey as of 2017 (Migration and Integration Report, 2018). ${ }^{10}$ Since the majority of Syrians live in Istanbul, almost $80 \%$ of all Syrians who gained Turkish citizenship recently also reside in Istanbul. Another interesting point in this process is that the government does not take applications at this point for Turkish citizenship, but determines who could be naturalized and gets in touch with them directly by calling them for interviews. Before the individual interviews, data obtained from the Health Ministry, Ministry of Education, Higher Education Board, Ministry of Labor and Social Security, and DGGM are evaluated and analyzed based on the following criteria: 1) Entering Turkey legally; 2) Staying under temporary protection and/or with a valid residence permit; 3) Having higher education-an undergraduate degree or above; 4) Having a profession; and 5) Not being involved in any criminal activity. ${ }^{11} \mathrm{Al}-$ though a good command of Turkish language by candidates is valued, it is not considered a sine qua non condition. In line with the criteria of granting Turkish citizenship, the initial evaluation process is carried out in conjunction with the Department of Immigration and Directorates of Population and Citizenship Affairs. Following the evaluation process, interviews with prospective candidates take place. For accepted cases, forms are submitted to the Council of Ministers for final approval. ${ }^{12}$

It is apparent that offering Turkish citizenship to Syrians has come with the change in policies and an understanding that they are no longer "guests," accepting that most of them are going to stay in Turkey either longterm or permanently. Therefore, we can say that the shift in the Turkish citizenship law is a direct outcome of recent migration flows. Although it might initially seem that the top-down decision to grant Turkish citizenship to Syrians was a simple political move by the governing elite, it did not happen in a political vacuum only, but depended heavily on social, economic and demographic factors. As is, the Turkish citizenship regime can be regarded as a continuation of the age-old policy, as the law still jealously guards criteria of ethnic descent and similar culture. The Syrians in Turkey who are mostly Sunni Muslims are considered "proper" migrants to be accepted because of their similar religious background. Moreover, almost one-third of Syrians already naturalized are reportedly either of Turkish descent, like Turkmen Syrians, or married to Turkish nationals (Sputniknews, 2018). Yet, other newly introduced criteria, such as having cultural and economic capital, are in line with the demands of the global economy and selective migration policies. Following the citizenship model of many countries in the global North, like Canada and the United States, by giving priority to the skilled and educated, Turkey not only

\footnotetext{
8 See Howard (2017) for a detailed discussion on statelessness in Syrian refugee children.

9 These changes were put into effect as of 6 April 2010 after publication in the Official Gazette (Decision No. 2010/139) numbered 27544.

10 The number of Syrians who acquired Turkish citizenship could be as high as 40,000 by the end of 2017 and is expected to eventually include 300,000 Syrians (interview with senior DGMM official on 7 December 2017). There are also other reports stating that between 2011 and $2016,7,827$ Syrians and 1,587 Iraqis obtained Turkish citizenship. See Turkish Interior Ministry's statement at Ministry of Interior (2017). According to an earlier public statement by the Directorate General on Population and Citizenship, the number of Syrians who earned Turkish citizenship between 2008 and 2013 was 3,577 while the number of Syrians who obtained Turkish citizenship through marriage to Turkish nationals by gender distribution was 839 men and 1,704 women.

11 According to the DGMM and Turkish National Security, the number of Syrians involved in criminal activities in Turkey is as low as $1.5 \%$.

12 Interview with a senior DGMM official on 7 December 2017.
} 
seeks greater acceptance by local populations of naturalized Syrians, but also hopes to meet domestic demand for skilled labor. If given proper jobs, the out-migration pressures on the remaining skilled Syrians will also be limited compared to previous years and can be utilized for the long-term benefit of the country in ways such as doing business with Syria and exerting soft power. Moreover, while giving citizenship to skilled and educated Syrians, Turkey displays its willingness to engage them in the integration processes of unskilled and uneducated Syrians. Demographic concerns regarding the shrinking population of Turkey is another factor. Because of the declining birthrates in Turkey, the country needs a young population. Currently, the demographic trends of Syrians in Turkey clearly suggest a young and dynamic population with 300 new babies born every day. Therefore, in the Turkish case, citizenship is used both as a reward for skilled individuals with economic and cultural capital and as a tool for the integration of other Syrians. It also demonstrates the other social, political and demographic concerns of the Turkish government.

\section{Research Methods}

The findings presented in this article are based on fieldwork carried out in Istanbul and Gaziantep from January 2016 to December 2017, funded primarily by Koç University College of Social Sciences and Humanities. These two cities were selected for methodological reasons, as each city hosts large populations of Syrians and have historical experience with integrating migrants. We conducted in-depth interviews with a total of 45 Syrian refugees, including those who had already acquired Turkish citizenship. Open-ended questionnaires were designed to enable the respondents to tell their stories in their own words, focusing primarily on their migration trajectories, experiences in Turkey, near-future plans and their thoughts about Turkish citizenship. We used qualitative content analysis to identify a set of common themes from the narratives and then employed a thematic coding system, which helped to create analytical categories. While we interviewed only one member of the household, in some cases group discussions and focus group interviews with Syrian women aged 18-45 and young gay men aged 18-27 enriched the interview data. The interviews were conducted in public places, such as cafes and restaurants, or other meeting points like NGO offices, workplaces and private homes. The length of stay of Syrian respondents in Turkey varied; while some migrated a year ago, others have been living in Istanbul and/or Gaziantep for more than four years. While the majority came to Turkey directly from Syria, others came after living in Lebanon or Egypt. Secondary migration within Turkey, especially to Istanbul, was also prevalent among the respondent group despite the restrictions imposed. Although our respondent group can- not be representative of the entire Syrian refugee population living in urban centers in Turkey, we made an effort to choose people with different profiles based on gender, ethnicity, socio-economic status and religion. The majority of Syrians interviewed were under temporary protection but there were also others who were staying in the country on residence permits. During the in-depth interviews, we worked closely with an interpreter who translated from Arabic to Turkish. We also conducted face-to-face interviews with 70 Turkish citizens to gauge their perceptions of Syrians' acquiring Turkish citizenship. Ethical approval for the project was gained via the university's ethics committee; consent forms were circulated to all participants before starting the interview process. Other than Syrian and Turkish respondents, we conducted interviews with some of the local (Syrian and Turkish) civil society actors working with Syrian populations as well as government officials from municipalities in Gaziantep and Istanbul and at the DGMM headquarters in Ankara.

\section{The Views of Syrians Regarding Citizenship in Turkey and Reactions by Local Populations}

The majority of Syrian refugees in Turkey experience limited access to proper accommodations and jobs and face problems of social and economic instability. Access to formal employment is often problematic. In January 2016, Turkey issued a new regulation allowing registered Syrian refugees, including skilled workers, to apply for work permits. Yet the number of Syrians with formal work permits remains limited even to this day. There are also further limitations on hiring Syrians: the number of Syrians employed by Turkish companies cannot exceed $10 \%$ of the total labor force and Syrians should have been in possession of Turkish identification documents for at least six months. ${ }^{13}$ For skilled and highly educated Syrians, deskilling and underemployment are common problems in Turkey (see Erdoğan, 2014, pp. 29-30; Sunata, 2017, pp. 5-6). Bloch (2004) argues that temporariness exacerbates the problems of refugees' ability to access resources, especially in the labor market, and constructs an obstacle to realizing longer term goals. Emphasizing that the need to find proper employment for skilled people should be a government priority instead of granting citizenship, one respondent underlines that job insecurity is the main reason for the departure of educated Syrians from Turkey:

I hope educated Syrians do not leave Turkey anymore. 5,000 Syrian doctors went to Germany last year alone. Turkey needs doctors and engineers but educated people cannot work in Turkey. In Germany, they start working immediately. Turkey should offer Syrians jobs, not citizenship. (Sunni-Arab, 61, male, Gaziantep)

\footnotetext{
13 Turkish Ministry of Labor and Social Security data indicates that only 4,019 Syrian refugees were granted work permits in 2015. The numbers slightly increased in 2016 reaching 13,298. See Ministry of Labor and Social Security (2015) and Al Jazeera (2016).
} 
Since $93 \%$ of all refugees and asylum seekers live in urban centers or semi-urban areas in Turkey, ${ }^{14}$ it literally means that in everyday life Syrian and Turkish nationals are in close contact with each other, either in the poor neighborhoods where they reside or in the workplace. While there are immediate benefits to living in cities-support of kinship networks, easier access to informal labor markets, healthcare, aid and cash assistance provided by international organizations and local civil society actorsthere is also growing resentment, overt and covert racism, exclusion and social problems in these urban areas. Turkish public opinion and the reactions of local people towards Syrian refugees show similarities to popular xenophobic discourses about migrants in most countries, such as "they will take our jobs," "the crime rate has increased," and "they will deplete our resources" (cf. Deniz, Ekinci, \& Hulur, 2016; Erdoğan, 2014; Öztürkler \& Göksel, 2015; Woods, Benvenuti, \& Kayali, 2016). Our Turkish respondents of varying socio-economic backgrounds also find it troublesome to give citizenship to Syrians; some suggested this should happen only if Syrian refugees meet certain high standards. Some also voiced a belief that the government would use Syrians with Turkish citizenship as a voting block and raised concerns that the poor and unskilled would stay whereas the skilled would eventually leave when the war was over:

The government should not have taken in too many refugees. After so many years, our hospitality wears out. Our own citizens have paid the price. Rents have increased and it has become difficult to find jobs. They [the government] brought them for political reasons, mainly to get more votes. As a Kurd from Turkey, it takes me longer to get a Turkish ID. Whatever rights I have, they have even more. They [Syrians] should not get Turkish citizenship. They will always put Syria first. They will commit crimes. Other states are not taking them in. Why should Turkey? They will never go back, there is nothing left in their country. (Kurdish, 55 , male, Istanbul)

I believe Turkey has taken this citizenship decision in a hasty manner, like all other issues regarding migration. The EU countries are not taking them [Syrians] in large numbers, not because there is xenophobia, but they have migration policies. The EU wants to accept skilled people only and Europeans think about how to integrate those refugees first. Turkey cannot meet all their social and economic demands. When the war is over, those with resources and property will go back and the unskilled masses will be left in Turkey. (Turkish, 58, female, Istanbul)

Anti-Syrian sentiment in Turkey increased in 2016 after the cross-border intervention and loss of Turkish soldiers' lives and again following the announcement that Syrian refugees living in Turkey would be granted citizenship. Other than recently occurring clashes between Syrian and Turkish nationals in certain cities, some of the racist discourse continues in various social media, including Twitter under hashtags such as \#suriyelilersınırdışıedilsin (deport Syrians). Discrimination and violence against Syrian refugees are reportedly on the rise in the border cities of Gaziantep, Şanlıurfa and Kilis (Simsek, 2015) and have spread to other cities, like Istanbul, Izmir, Sakarya and Konya (see International Crisis Group, 2018, pp. 3-5). Our Syrian respondents also acknowledged that they have become the target of discriminatory remarks and unwelcoming behaviors. The lack of language competence creates further barriers in establishing good relationships with members of the receiving society, leaving them with a feeling of exclusion as stated in these excerpts:

A Turkish man tried to shoot me in front of our restaurant. He tried to kill me. He is a drunk guy, living on the streets. Nobody was hurt. The police came to take him in, but the very next day he was on the streets again. All eyes are on us. (Sunni-Arab, 35, male, Gaziantep)

We don't have Turkish friends. The language is an important factor. Plus, we don't share the same culture. We are different. When I talk to a Turkish gay, he is only into sex with me. He doesn't care about what I feel or try to be in a relationship. They also look down on us as we are refugees. I find people ethnocentric here. They have a prejudice against Syrians. If I talk in Arabic on public transportation, they stare at us. One day, a man shouted, "Go back to your country. Our sons are fighting in Syria, but you are comfortable here in Turkey." (Syrian-Orthodox, 24, gay, Istanbul)

Regardless of the discriminatory attitudes they face, many of our Syrian respondents stated that they prefer to live in Turkey rather than in Europe. The main reasons they choose to live in Turkey are its geographical and cultural proximity to Syria, the political instability in Syria, and a desire to maintain close links with their homeland through business interactions. Xenophobia and antiimmigrant sentiments in Europe, the perilous journeys taken transiting Turkey, and the experiences of many Syrian friends and relatives in Europe deterred them from going further west. Today, the public, academia and policy circles have uniformly accepted that Syrians are going to stay in Turkey much longer than initially expected. Offering Turkish citizenship to Syrians, therefore, is part of the change in migration policies and the understanding that Syrians are not "guests" anymore. Returning to their homeland is out of the picture for many, especially those who lost everything in the civil war and those opposing the Asad regime. Repatriation occurs only when the

\footnotetext{
${ }^{14}$ A total of 227,644 , less than $7 \%$ of Syrians, stay in the 21 camps located in 10 provinces in Turkey; the remaining Syrians mainly live in border cities and metropolitan areas, such as Istanbul, Şanlıurfa, Hatay, Gaziantep, Mersin, Adana, Bursa, Kilis, Izmir and Kahramanmaraş (information compiled from DGGM, 2018).
} 
problems causing displacement are eliminated; these include lack of employment and markets, losing land and property ownership, unavailability of schools and health care, and inability to access clean water, housing, and sanitation (Kibreab, 2003, p. 39). A Syrian Arab woman in her late 30s working in a shop in Sultanbeyli, Istanbul stated the reasons why she would like to stay in Turkey even if she could not get Turkish citizenship:

We lost everything-our jobs, our house, our lives too. I want to see my children grow up in peace-that's all I care about. We lived a horrible experience. There was death everywhere. You simply walk on dead people. You smell death everywhere. The streets were like rivers of blood. I could not forget that. We are grateful to Turkey. Oil-rich Muslim countries shut their doors. Europe shuts the door. Return? I don't have anything there. Why should I go back? For what? No house, no job, no money to fix anything. Our memories are lost. Our lives are lost. They [Asad forces] not only ruined our houses but our idea of home. Turkey is like Syria, the same religion. I don't expect that they will make me a Turkish citizen. I am not a doctor, I am not an engineer. But I am happy here without being a citizen. Turkey is my home already. I feel that. (Sunni-Arab, 37, female, Istanbul)

Others with more resources also suggest that a mix of social and political problems impede their will to return to Syria for good:

The future for Syria is not very promising. Even when the war is over, it will become worse. We need strong leaders to keep the country united. Nobody trusts the Asad regime anymore. Stories in Syria are horrible. What Asad has done to his own country is without comparison and unprecedented in history. (SunniArab, 61, male, Gaziantep)

Most of our Syrian participants are in favor of obtaining citizenship in Turkey on the condition that they are able to keep their Syrian citizenship. ${ }^{15}$ Transnational citizenship supports the relationships between individuals in two or more independent states and highlights membership-based rights and obligations (Bauböck, 2007). Our respondents mainly opt for dual citizenship as they do not want to cut their symbolic and economic ties with Syria:

I do not want to leave my Syrian citizenship. I was born and grew up in Syria. I have worked in Syria and would like to get my pension from Syria. (Syrian-Turkmen, male, 54, Gaziantep)

I want Turkish citizenship very much for myself and for my son. Only then I will not feel different. I will be like other Turks. No one can use me, and I will have the same rights. My son is stateless as his father was Palestinian. But I cannot leave Syrian citizenship. Syria is my homeland. (Sunni-Arab, 50, female, Istanbul)

The respondents above highlighted the need to be mobile and the importance of not losing the rights that Syrian citizenship offers them. Their determination to retain dual citizenship validates the statement that citizenship is no longer an issue of nationality, but represents "the political mechanisms that make people into citizens which takes account of access to equal rights, the needs, interests and values of citizens as members of social and cultural collectivities" (Castles \& Davidson, 2000, p. 24). Citizenship further represents safety and security for most refugees, rather than only facilitating their integration process (Morrell, 2009). Having access to citizenship also confers "normalcy" and access to rights for many Syrians, as their temporary protection status does not guarantee permanent protection and most of them have lost their hope that the war in Syria would end soon. While doing fieldwork, we also met Syrians who have already acquired Turkish citizenship. They also mentioned that despite earning Turkish citizenship, they would like to go back for different reasons:

Vatan [the motherland] is where I was born. Having a nationality is not enough, you need to have rights in your country. My wife earned Turkish citizenship through her mother. Therefore, our children also received Turkish citizenship. I was not interested in having Turkish citizenship at first. Before 2012, I was doing business with a Turkish medical company while in Syria. Asad forces arrested me at the airport. After 910 days, they set me free. Then I applied for Turkish citizenship. I had an interview at the Turkish Consulate in Aleppo. Depending on the political situation after the war, I want to go back to Syria. I am a member of the opposition party. (Sunni-Arab, 45, male, Gaziantep)

I became Turkish citizen in May 2016 with the rest of my family and my eight brothers living in Turkey. Our whole village got citizenship. Our ancestors were Ottoman soldiers and some of our family members stayed in Turkey while we stayed in Syria. We feel more secure now and protected by law. But most [Turkish] people think I am still a Syrian. Then I show them my kimlik [Turkish ID card]. Now as a Turkish citizen, I have to pay for healthcare and I cannot get cash assistance for education for my kids from international organizations. Plus, I cannot have a second wife in Turkey! As Turkmens, we also have a responsibility to go back to Syria and maintain our existence there. (Syrian-Turkmen, 43, male, Gaziantep)

\footnotetext{
15 This is also in line with another qualitative study larger in scale carried out in 10 cities in Turkey in which $74 \%$ of respondents showed an interest in Turkish citizenship. See report released by the Human Development Foundation (Sunata, 2017).
} 
These quotes show that citizenship is not associated with a sense of national belonging anymore, especially in the case of Syrian refugees. It instead represents a status which provides protection and access to rights rather than signifying emotional links. In their case, citizenship does not immediately guarantee inclusion in Turkish society, but is an ongoing process. The meaning refugees give to citizenship, their decision-making processes and active participation supports new practices of citizenship which refer to safety, acceptance by the wider society, access to rights and a multiplicity of memberships.

\section{Conclusion}

This article has presented findings on acquiring Turkish citizenship, both from the perspective of Syrian refugees and Turkish nationals while analyzing the reasons for changes in citizenship policy from the perspective of the Turkish state. As illustrated by the empirical data, Syrian refugees in Turkey are in favor of dual citizenship because of access to rights in both countries, increased mobility, retirement options, and business opportunities in two countries. We suggest that the reasons for the preference of dual citizenship do not only reflect feelings of national belonging, but also highlight the importance of guarding civil, political and economic rights in both countries, thus having more life choices.

Through the use of different regulations, polities have always tried to determine who can be included as a citizen and who should be excluded (Heyman, 2018, p. 45). In the Turkish case, the dramatic shift in the understanding of citizenship and the recent inclusion of previously excluded groups, like migrants, have taken place due to mass migration flows and the pressures to successfully integrate migrants into Turkish society. Policy changes further reflect the necessity of reconciling the need to integrate the Syrian population with the need to facilitate their acceptance by the host society amidst rising tensions in many major cities in Turkey. Demographic concerns regarding the shrinking population of Turkey and political factors, such as the fear of losing all qualified Syrians to the West and the possible backlash if unskilled masses are given citizenship, are other important drivers of these policy changes.

However, as stated by Heyman, "citizenship is not only inclusive but also exclusive, giving rise to social boundaries of insider and outsider" (2018, p. 46). One big question is what will happen to the vast majority of Syrians who will not be given Turkish citizenship? It seems that many Turkish people (86.2\%), regardless of their political affiliations and voting behavior, are united in their wish for the repatriation of Syrians once the war is over. ${ }^{16}$ In our interviews, we also found that Turkish nationals had no affinity towards Syrian culture despite a common Islamic heritage, whereas for Syrians, the cul- tural similarity to Turks and proximity to their homeland were cited as major reasons for their wish to stay in Turkey. Nowadays, due to public perceptions and the upcoming 2019 presidential elections in Turkey, official discourse has taken the form of the eventual safe return of Syrian refugees and providing a safe zone for returnees, as Turkey cannot keep Syrians within its territory forever (Hürriyet, 2018). So far, 130,000 Syrians have returned to Syria after a safe zone inside Syria was secured in the wake of the "Euphrates Shield" Operation. An ongoing military operation named "Olive Branch" was launched across Turkey's borders in yet another attempt to provide a safe area that can facilitate repatriation after clearing the area from Kurdish separatist groups. Yet, numerous reports and our study alike suggest that a mass return is unlikely given the social, economic and political situation in Syria. ${ }^{17}$

Another question is whether granting citizenship will ensure Syrians' integration in Turkish society. There is evidence that skilled and educated individuals have more cultural and social capital to integrate. Moreover, they are usually more equipped in claims-making. But, as we have seen in the UK, France, Belgium, and Germany, citizenship alone is not enough to foster integration or eliminate discrimination and social exclusion in society. Integration policies for refugees and natives alike are urgently needed, in addition to good governance in migration management and the provision of direct financial assistance to local administrations that have been proven to play a pioneering role in integration. The Sultanbeyli and Esenler Municipalities in Istanbul and the Gaziantep Metropolitan Municipality have been doing impeccable work in terms of integration since 2014. Turkey followed an open-door policy until 2017 and indeed adopted a very humanitarian and compassionate approach towards Syrian refugees, spending almost 30 billion USD and receiving limited funds of around 900 million Euro to alleviate some of the burden. There is still much to be done in terms of the education of Syrian children and provision of employment. The schooling ratio of Syrian children has tremendously increased from $30 \%$ in $2015-16$ to $62 \%$ in 2017-18 school year (International Crisis Group, 2018, p. 18). The remaining $38 \%$ are currently out of school and should serve as an alarm signal of lost generations and delinquency. As for employment, the number of Syrians with access to decent jobs is still very limited. Although there are 8,000 to 10,000 registered Syrian businesses operating in Turkey, and the number of Syrians legally employed increased to almost 20,000 as of early 2018, it is estimated that almost one million Syrians are currently employed in the informal sector with minimal pay and no social security (International Crisis Group, 2018, p. 17).

The rhetoric surrounding "ensar-muhajir" allowed many faith-based civil society actors to actively work to extend humanitarian aid to Syrian refugees out of

\footnotetext{
16 Initial results of the survey titled "Dimensions of Polarization in Turkey" conducted by the German Marshall Fund and Istanbul Bilgi University Centre for Migration Research (Centre for Migration Research, 2018). See also Turkish Daily News (2018).

17 See, for example, International Crisis Group (2018, p. 22) and Kirişçi \& Ferris (2015).
} 
an Islamic duty towards co-religionists. As recently mentioned by Turkish Prime Minister, Binali Yıldırım, at the Symposium on Migration and Integration on 15 December 2017 in Ankara:

Assimilation policy does not exist in our belief system, in our culture and in our state traditions. Our relationship with refugees was based on muhajir and ensar. The main duty of migrants is to integrate with the [Turkish] society and to obey the laws. One thing we cannot tolerate is migrants disregarding this country's values. ${ }^{18}$

Yet, it is high time to discard this discourse and focus on a rights-based approach instead. No matter how citizenship is defined, it confers civil, social, cultural and economic rights. It is clear that Turkey cannot be expected to give citizenship to all Syrians living in Turkey. Giving them permanent residence, however, could be one way to ensure social inclusion. In any case, a well-structured integration policy is needed to safeguard the rights given to refugees and should be fully implemented. Otherwise, the current social problems and ongoing resentment towards Syrians will only accelerate. As we write this article, a National Integration Plan is underway and is expected to cover major areas like employment, education, healthcare and the elimination of discrimination. ${ }^{19} \mathrm{Nev}$ ertheless, it is almost certain that the integration of Syrian refugees will be among the top three agenda items in Turkey in the coming years.

\section{Acknowledgments}

We would like to thank the editors of this issue and two anonymous referees for their comments on the earlier version of this article.

\section{Conflict of Interests}

The authors declare no conflict of interests.

\section{References}

Ager, A. \& Strang, A. (2004). Indicators of integration (Final Report). London: Home Office.

Ager, A., \& Strang, A. (2008). Understanding integration: A conceptual framework. Journal of Refugee Studies, 21(2), 166-191.

Al Jazeera. (2016, July 25). Syrian refugees: Struggles in Turkey intensify. Retrieved from http://aje.io/tn9w

Bauböck, R. (2007). Stakeholder citizenship and transnational political participation: A normative evaluation of external voting. Fordham Law Review, 75, 2393-2447.

Bauböck, R. (2008). Stakeholder citizenship: An idea whose time has come? Washington, DC: Migration Policy Institute.

Bloch, A. (2000). Refugee settlement in Britain: The impact of policy on participation. Journal of Ethnic and Migration Studies, 26(1), 75-88.

Bloch, A. (2004). Making it work: Refugee employment in the UK. Asylum and Migration (Working Paper, No. 2). London: Institute for Public Policy Research.

Castles, S. \& Davidson, A. (2000). Citizenship and migration: Globalization and the politics of belonging. New York: Routledge.

Castles, S., Korac, M., Vasta, E., \& Vertovec, S. (2002). Integration: Mapping the field (Home Office Online Report 29/03). London: Home Office.

Centre for Migration Research. (2018). Dimensions of polarization in Turkey. Retrieved from https://goc. bilgi.edu.tr/media/uploads/2018/02/06/dimensionsof-polarizationshortfindings_DNzdZml.pdf

Deniz, A. C., Ekinci, M., \& Hulur, A. B. (2016). Bizim müstakbel hep harap oldu: Suriyeli sığınmacıların gündelik hayatı: Antep-Kilis çevresi. Istanbul: Bilgi University Publications.

Directorate General of Migration Management of Turkey. (2016). Amendments made to law. Retrieved from http://www.goc.gov.tr/files/files/kanunda_yapilan_ degisiklikler_eng_270916.pdf

Directorate General of Migration Management of Turkey. (2018). Temporary protection. Retrieved from http:// www.goc.gov.tr/icerik6/temporary-protection_915_ 1024_4748_icerik

Erdoğan, M. M. (2014). Syrians in Turkey: Social acceptance and Integration research. Hacettepe University Migration and Politics Research Centre. Retrieved from http://fs.hacettepe.edu.tr/hugo/dosyalar/Turk iyedekiSuriyeliler-Syrians\%20in\%20Turkey-Rapor-TREN-19022015.pdf

Giddens, A. (1991). Modernity and self-identity. Cambridge: Polity Press.

Hammar, T. (1990). Democracy and the nation state. Aldershot: Avebury.

Heyman, J. (2018). Immigration or citizenship? Two sides of one social theory. In E. Castaneda (Ed.), Immigration and categorical inequality: Migration to the city and the birth of race and ethnicity (pp. 44-64). New York: Routledge.

Howard, D. M. (2017). Analyzing the causes of statelessness in Syrian refugee children. Texas International Law Journal, 52(2), 281-312.

Hürriyet. (2018, February 8). Son dakika...Erdoğan'dan Suriyeli mesajı: 3.5 milyonu burada ilanihaye saklayacak değiliz. Retrieved from http://www.hurriyet.com. tr/son-dakika-erdogandan-suriyeli-mesaji-3-5-milyo nu-burada-ilanihaye-saklayacak-degiliz-40735253

International Crisis Group. (2018). Turkey's Syrian refugees: Defusing metropolitan tensions (Europe

\footnotetext{
18 See details of Turkish Prime Minister Binali Yıldırım's speech at the Migration and Integration Symposium. Retrieved from https://www.haberler.com/ goc-ve-uyum-sempozyumu-10351765-haberi (15 December 2017).

19 Personal interview with DGMM senior official on 7 December 2017 in Ankara.
} 
Report no: 248). Brussels. Retrieved from https:// d2071andvip0wj.cloudfront.net/248-turkey-s-syrianrefugees.pdf

Joppke, C. (2007). Transformation of citizenship: Status, rights, identity. Citizenship Studies, 11(1), 37-48.

Kaya, A. (2012). Transnational citizenship: German-Turks and liberalizing citizenship regimes. Citizenship Studies, 16(2), 153-172.

Kibreab, G. (2003). Citizenship rights and repatriation of refugees. International Migration Review, 37(1), 24-73.

Kirişçi, K. (2000). Disaggregating Turkish citizenship and immigration practices. Middle Eastern Studies, 36(3), 1-22.

Kirişçi, K., \& Ferris, E. (2015). Not likely to go home: Syrian refugees and the challenges to Turkey and the international community (Turkey Project Policy Paper, No. 7). Brookings Institution. Retrieved from https:// www.brookings.edu/wp-content/uploads/2016/06/ Turkey-Policy-Paper-web.pdf

Koser Akcapar, S. (2018). International migration and diplomacy: Challenges and opportunities in the 21st century. In S. Koser Akcapar (Ed.), Perceptions. Ankara: Turkey.

Koska, V. (2015). Refugee integration and citizenship policies: The case study of Croatian Serbs in Vojvodina. Ethnopolitics, 14(2), 180-196.

Kymlicka, W. (2003). Immigration, citizenship, multiculturalism: Exploring the links. The Political Quarterly, 74(1), 195-208.

Massey, D. S., \& Bartley, K. (2005). The changing legal status distribution of immigrants: A caution, International Migration Review, 39(2), 469-484.

Migration and Integration Report. (2018). TBMM insan Haklarını inceleme Komisyonu, Mülteci Hakları Alt Komisyonu raporu (in Turkish). Ankara: TBMM.

Milliyet. (2016, July 2). Cumhurbaşkanı Erdoğan'dan Suriyelilere Vatandaşlık Müjdesi. Retrieved from http://www.milliyet.com.tr/cumhurbaskani-erdogan -dan-suriyelilere-kilis-yerelhaber-1455405

Ministry of Interior. (2017). Statement. Retrieved from https://www.icisleri.gov.tr/basin-aciklamasi30 092017

Ministry of Labor and Social Security. (2015). Work permits for foreigners statistics 2015. Retrieved from http://www.csgb.gov.tr/media/3209/yabanci izin2015.pdf

Morrell, G. (2009). Refugee rights and responsibilities in the UK. London: Information Centre on Asylum and Refugees (ICAR).

Nunn, C., McMichael, C., Gifford, S. M., \& Correa-Velez, I. (2016). Mobility and security: The perceived benefits of citizenship for resettled young people from refugee backgrounds. Journal of Ethnic and Migration Studies, 42(3), 382-399.

Öztürkler, H., \& Göksel, T. (January 2015). The economic effects of Syrian refugees on Turkey: A synthetic modelling (Orsam Report, No. 196). Ankara: Orsam and Tesev.

Simsek, D. (2015, January 29). Anti-Syrian racism in Turkey. Retrieved from https://www.opendemo cracy.net/north-africa-west-asia/dogus-simsek/anti syrian-racism-in-turkey

Smyth, G., Stewart, E., \& Da Lomba, S. (2010). Critical reflections on refugee integration: Lessons from international perspectives. Journal of Refugee Studies, 23(4), 411-414.

Soysal, Y. (1994). Limits of citizenship: Migrants and postnational membership in Europe. Chicago, IL: University of Chicago Press.

Sputniknews (2018, January 18). TBMM, Türkiye'deki Suriyelilerin röntgenini çekti. Retrieved from https:// tr.sputniknews.com/turkiye/201801181031873614tbmm-turkiye-suriyeliler-rontgenini-cekti

Stewart, E., \& Mulvey, G. (2014). Seeking safety beyond refuge: The impact of immigration and citizenship policy upon refugees in the UK. Journal of Ethnic and Migration Studies, 40(7), 1023-1039.

Strang, A., \& Ager, A. (2010). Refugee integration: Emerging trends and remaining agendas. Journal of Refugee Studies, 23(4), 589-607.

Sunata, U. (2017). Monitoring lives of Syrian refugees in Turkey (Report by INGEV-Human Development Foundation). Retrieved from http://ingev.org/ kutuphane/ingev-raporlar/suriyeli-multeci-hayatlarmonitoru-degerlendirme

Turkish Daily News. (2018, February 6). Politically polarized Turkey finds largest common ground in Syrian refugees' return. Retrieved from http://www. hurriyetdailynews.com/politically-polarized-turkeyfinds-largest-common-ground-in-syrian-refugees-re turn-126873

Turton, D. (2003). Conceptualising forced migration (RSC Working Paper, No. 12). Oxford: University of Oxford.

Turner, V. (1974). Dramas, fields, and metaphors: Symbolic action in human society. Ithaca: Cornell University Press.

Van Gennep, A. (1908). Rites of passage. London: Routledge and Kegan Paul.

Vertovec, S. (2006). The emergence of super-diversity in Britain. Centre on Migration, Policy and Society (Working Paper, No. 25). Oxford: University of Oxford.

Woods, A., Benvenuti, B., Kayali, N. (2016). Syrian refugees in Istanbul (Workshop Report). Istanbul: IPC Center. 


\section{About the Authors}

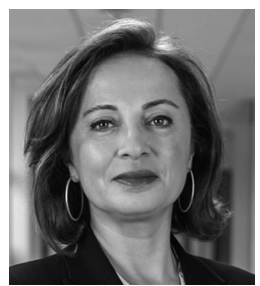

Sebnem Koser Akcapar (PhD) currently works as Associate Professor at the Sociology Department, Koç University, Istanbul. She is a Senior Research Fellow and executive board member at Migration Research Center (MiReKoc) and the founding Director of Center for Asian Studies (KUASIA) at the same university. She also holds a position as an associate member at the Asia Centre at University of Sussex. Her research areas include feminization of migration, asylum seekers and refugees, labor migration, skilled migration, diaspora formation and political mobilization. Her current projects include Chinese migrant entrepreneurs, and Syrian refugees in Turkey and in the Middle East, and a multi-sited project on migrant youth integration titled "Peacemakers".

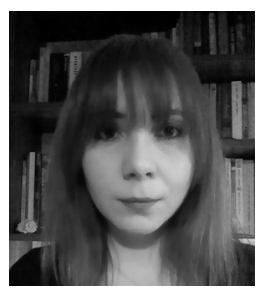

Dogus Simsek (PhD) currently teaches at the College of Social Sciences and Humanities at Koç University. She previously carried out her own research project entitled 'The Experiences of Urban Syrian refugees in Turkey and Turkey's Migration Policy', funded by TUBITAK at Migration Research Centre (MireKoc) at Koç University. She received her PhD in Sociology from City University London and MA in Cultural Studies from Goldsmiths College, University of London. Her research interests broadly cover integration and transnationalism, refugee studies, racism and second generation identity. 